Provided for non-commercial research and education use. Not for reproduction, distribution or commercial use.

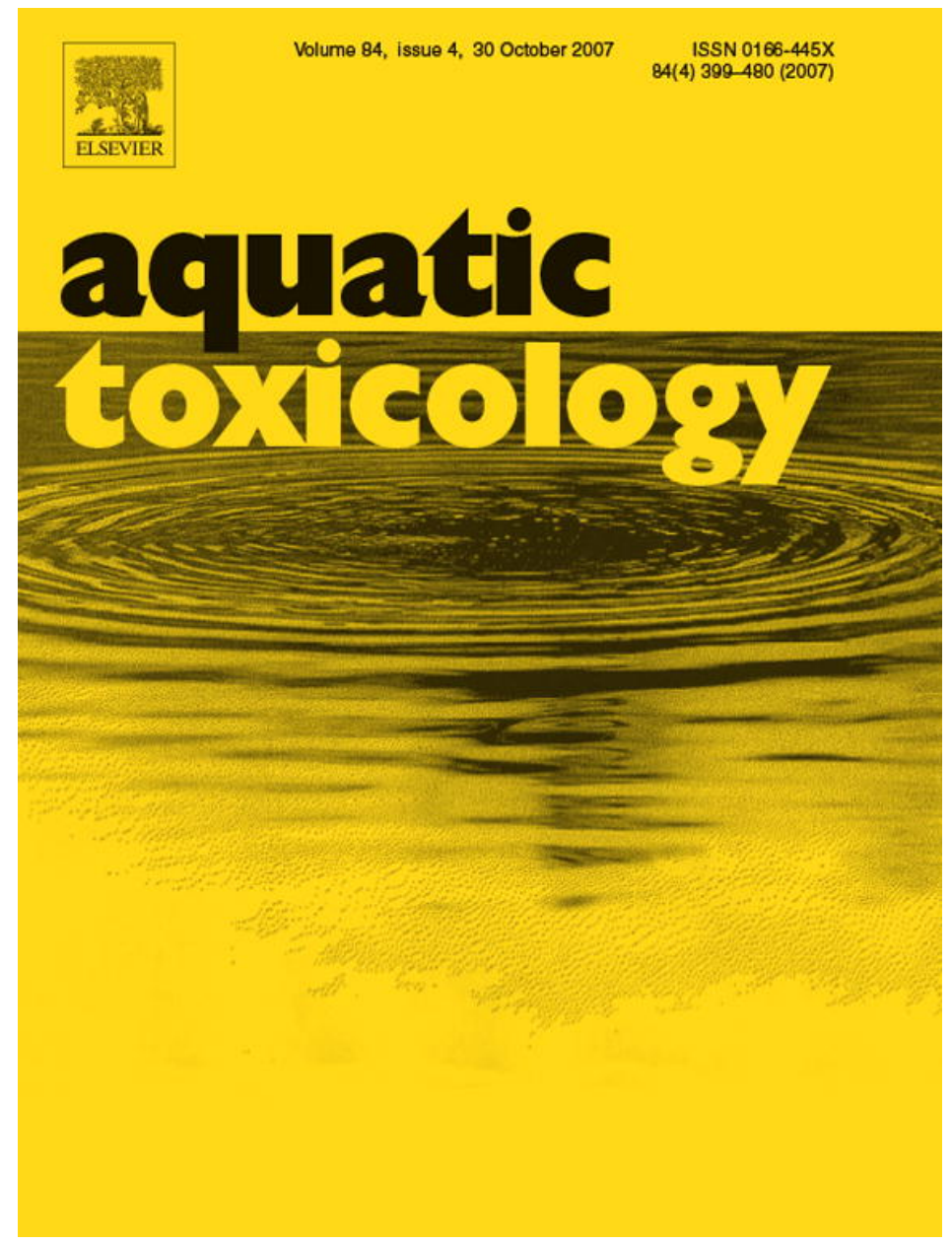

This article was published in an Elsevier journal. The attached copy

is furnished to the author for non-commercial research and education use, including for instruction at the author's institution, sharing with colleagues and providing to institution administration.

Other uses, including reproduction and distribution, or selling or licensing copies, or posting to personal, institutional or third party websites are prohibited.

In most cases authors are permitted to post their version of the article (e.g. in Word or Tex form) to their personal website or institutional repository. Authors requiring further information regarding Elsevier's archiving and manuscript policies are encouraged to visit: 


\title{
Is the umbo matrix of bivalve shells (Laternula elliptica) a climate archive?
}

\author{
D. Dick, E. Philipp, M. Kriews, D. Abele* \\ Alfred Wegener Institute for Polar and Marine Research, Am Handelshafen 12, 27570 Bremerhaven, Germany
}

Received 12 June 2007; received in revised form 16 July 2007; accepted 16 July 2007

\begin{abstract}
Heavy metal accumulation into bivalve soft tissues has received increasing interest in recent years with respect to biomonitoring of environmental change including pollution. To a lesser extent, accretion of elements from the environment into bivalve hard structures (shells) has been investigated, although the importance of the shells as environmental archives has been acknowledged. Here we report element distribution within consecutive growth bands in the shells of the Antarctic soft shell clam Laternula elliptica, which is currently exposed to vast environmental change in Antarctic Peninsula coastal environments that undergo rapid climate warming. We performed a high spatial resolution analysis for $\mathrm{Al}, \mathrm{Fe}, \mathrm{Mn}, \mathrm{Cu}, \mathrm{Pb}$ and $\mathrm{U}$ in the shell umbo, by means of laser ablation inductively coupled plasma mass spectrometry (LA-ICP-MS). Element ratios within the umbo did not resemble either the ratios in the surrounding seawater, the sedimenting material in Potter Cove, or even the Earth's crust basal composition. Mn and $\mathrm{Cu}$ were preferentially incorporated into the umbo. A strong decrease of element accretion with time could be related to lifetime respiration mass $(R)$ of the animals. This indicates element accretion into the umbo and shell matrix to be largely a function of animal ecophysiology and life history, and these effects need to be considered in the context of potential usefulness of L. elliptica shells as environmental archives.
\end{abstract}

(C) 2007 Elsevier B.V. All rights reserved.

Keywords: Trace metals; Bivalve shell archives; Laser ablation

\section{Introduction}

The analysis of the element composition of bivalve shells has gained importance in recent years with respect to environmental monitoring. Bivalves are filter feeders and accumulate inorganic elements and organic compounds from the water column through ingestion of sediment particles (Jing et al., 2006). It is tempting to assume that the rates at which molluscs incorporate ingested elements into newly grown shell should linearly depend on the element composition of the surrounding water over the years (Carriker et al., 1982). For that matter, many publications demonstrate exposure to elevated dissolved or complexed heavy metals to cause increased soft tissues concentrations in aquatic animals including bivalves (e.g.: Yap et al., 2003 for $\mathrm{Cd}, \mathrm{Cu}$, $\mathrm{Pb}, \mathrm{Zn}$; Jing et al., 2006 for $\mathrm{Cu}$; Bagnyukova et al., 2006 for iron uptake in goldfish). However, uptake of heavy metals into aquatic organisms, especially of the biologically essential metals like $\mathrm{Cu}$, underlies complex physiological regulation by the

\footnotetext{
* Corresponding author.

E-mail address: Doris.Abele@awi.de (D. Abele).
}

animals. Moreover, the uptake may be modified by environmental parameters like water temperature, $\mathrm{pH}$ and oxygenation, and modifications can differentially affect different metals. Thus, Huanxin et al. (2000) did not find a simple linear relationship between the concentration of heavy metals in oyster tissue and shells and the environment. Instead, $\mathrm{Cu}$ and $\mathrm{Zn}$ were greatly enriched in oyster tissue, which the authors attributed to the absolute physiological requirement for these elements. Further, $\mathrm{Cd}$ was enriched in the shell presumably due to the easy substitution of Ca by $\mathrm{Cd}$ (ionic radius $\mathrm{Ca} 9.7$ and $\mathrm{Cd} 9.8 \mathrm{~nm}$ ). Mubiana and Blust (2007) examined the effects of temperature on accumulation of various metals by the blue mussel Mytilus edulis. Sequestration of non-essential metals like $\mathrm{Cd}$ and $\mathrm{Pb}$ correlated positively with temperature, whereas uptake of other species like Co did not show temperature dependency. However, the concentrations of all investigated elements declined in M. edulis soft tissue over time when animals were kept in metal-free artificial seawater, which was prepared with high purity salts, indicating that the outside concentrations still have a major impact on the uptake and release of metals into blue mussel soft tissues.

Metals, sequestered into bivalve tissues are translocated to the mantle, the tissue surrounding the animals' soft body. From the 
outside epidermis of the mantle the elements are released into the extrapallial fluid, located between mantle and clam shell. From this extrapallial fluid the ions are incorporated into the inner surface of the newly forming calcium carbonate skeleton (Tynan et al., 2005). Therefore, once knowing how the specific physiological requirements and adaptations of a species modify element uptake into soft tissues, it might be possible to deduce past environmental metal concentrations from the shell archive of yearly forming growth bands (Price and Pearce, 1997; Richardson et al., 2001).

The use of mollusc shells as proxies for environmental change including pollution events creates the necessity to analyse single year bands within the shell. A variety of techniques to detect minor and trace elements in the shells are described by Richardson (2001). Laser ablation inductively coupled plasma mass spectrometry (LA-ICP-MS) is one of the newer techniques, enabling analysis of a wide range of elements in shellfish (Raith et al., 1996; Richardson et al., 2001). LA-ICP-MS offers high spatial resolution analysis, less sample preparation and, therefore, reduces possibilities for sample contamination. Considering sample preparation and analysis it is a fast method compared to liquid ICP-MS.

The present study analyses metal ( $\mathrm{Al}, \mathrm{Fe}, \mathrm{Mn}, \mathrm{Cu}, \mathrm{Pb}, \mathrm{U})$ variations in Laternula elliptica shells (Antarctic soft shell clam) to see how accretion of elements in bivalve hard structures changes over time in successively deposited growth bands. Samples were taken in Potter Cove on King George Island, Antarctica, fronting the Collins glacier. High loads of particulate and dissolved iron are transported into Potter Cove during the austral summer season with glacier melt water run-off (Schloss et al., 2007; Abele et al., 2007), creating an interest in the idea that bivalve shells might be useful archives of long-term changes of environmental iron load under conditions of climate-induced glaciers melting in the Antarctic Peninsula region (Dierssen et al., 2002).

\section{Materials and methods}

\subsection{Bivalve shell sampling}

Live specimens of the Antarctic soft shell clam, L. elliptica, were collected in 2003 at $10 \mathrm{~m}$ water depth in Potter Cove in front of the Argentinean Jubany station on King George's Island (Position: $62^{\circ} 14^{\prime} \mathrm{S}, 58^{\circ} 40^{\prime} \mathrm{W}$ ). The Antarctic bivalve (L. elliptica) has a maximum lifespan of $>36$ years (Philipp et al., 2005) and is a major circum-Antarctic biomass component, colonizing muddy sediments in coastal environments. It is a key species of the Antarctic bentho-pelagic carbon flux (Momo et al., 2002).

Shells of the four oldest animals were cut through the umbo with a diamond saw (Buehler, Isometh, Germany) and wet polished with sandpaper (400 and 600 grain size, see Philipp et al., 2005). The age determination by annual deposited rings within the shell umbo (Brey and Mackensen, 1997) showed that three animals were 23 years old $(* 1980)$, and one 21 years old (*1982). Fig. 1 shows an example of a cut and polished umbo of L. elliptica after laser ablation with clearly visible annual growth bands.

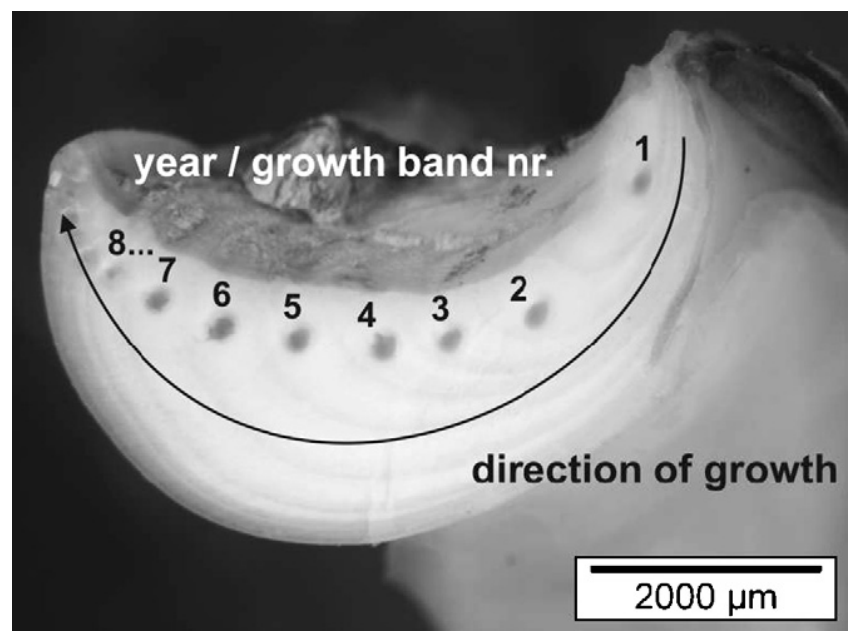

Fig. 1. Cut and polished umbo of Laternula elliptica after laser ablation with clearly visible annual growth bands. Photo by K. Beyer.

\subsection{Laser ablation analysis}

Annual growth bands, visible within the umbo, were analyzed for $\mathrm{Al}, \mathrm{Mn}, \mathrm{Fe}, \mathrm{Pb}$ and $\mathrm{U}$ with laser ablation inductively coupled plasma mass spectrometry (LA-ICP-MS; Quanta-Ray® GCR11 Spectra Physics 1064 nm; Elan 6000 Perkin-Elmer/Sciex). An overview of the optimized operation condition parameters used is given in Table 1. The experimental setup for the direct analysis of solid samples is shown by Reinhardt et al. (2001) and Kriews et al. (2004a, 2004b). We used a $1064 \mathrm{~nm} \mathrm{Nd:YAG}$ laser (Nd-doped $\mathrm{Y}-\mathrm{Al}$ garnet). The focused laser beam targets the sample inside the cryogenic chamber and ablates the sample surface. Spot sizes of approximately $200 \mu \mathrm{m}$ were achieved (Fig. 1). At the front side of the chamber the carrier gas argon passes through the ablation cell and transports the ablated material into the connected ICP-Quadrupol MS, where the elements from the sample are ionised, separated, and isotopes detected.

Table 1

Operating conditions for the laser ablation inductively coupled plasma mass spectrometer system (LA-ICP-MS)

Inductively coupled plasma mass spectrometer Perkin-Elmer Sciex Elan 6000

Radio frequency power

$1400 \mathrm{~W}$

Plasma gas

Auxiliary gas

Carrier gas

Dwell time

Sweeps/replicate

Replicate

14.0 $\mathrm{L} \mathrm{min}^{-1}$

$0.8 \mathrm{~L} \mathrm{~min}^{-1}$

$1.0 \mathrm{~L} \mathrm{~min}^{-1}$

$10 \mathrm{~ms}$

20

5

Laser system

Quanta-Ray® GCR-11 Spectra Physics

Wavelength

Mode

Q-switch time

Excitation lamp energy

Laser energy

Pulse frequency

Laser scan mode

Focus

Spot size $1064 \mathrm{~nm}$

Q-switch

$220 \mu \mathrm{s}$

$50 \mathrm{~J}$

$200 \mathrm{~mJ}$

$10 \mathrm{~Hz}$

Point scan

On sample surface

$200 \mu \mathrm{m}$ 

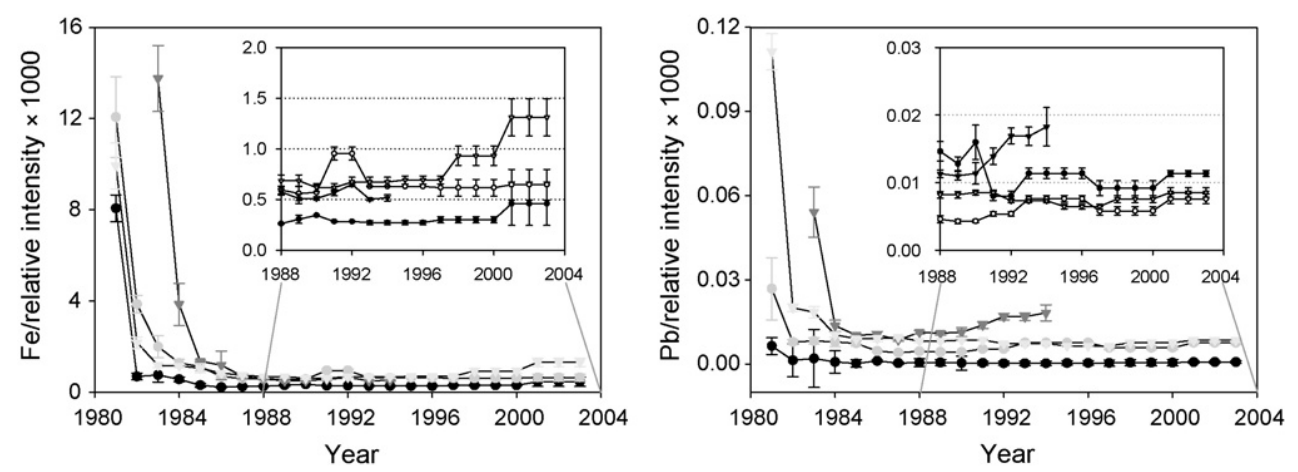

Fig. 2. Relative intensities \pm S.D. $(\times 1000)$ of iron and lead in annual growth bands of four different L. elliptica between 1980 and 2003 . Small diagrams show a magnification of the time course from 1988 to 2003. Yearly resolution was obtained until an age of 12. After this age mean values for groups of up to 4-year bands were calculated, due to the spot size of the laser crater. The same weighted value was assigned to each year in a group.

An integrated microscope was used to target the laser beam to different growth bands of the sample shells. In case the diameter of the laser crater exceeded growth band thickness, mean values of more than one growth band were derived. As matrix matched standards were not available, no element concentrations are provided in this paper. Instead, normalized element signatures are shown.

Each matrix has its specific absorption coefficient at different wavelengths. The $1064 \mathrm{~nm}$ wavelength is best suitable for laser ablation of ice cores, which is usually performed in our laboratory. The energy is sufficiently high for intrusion into the ice core, resulting in efficient sample ablation, a process called photoablation (Pearce et al., 2004). If the wavelength is not optimal for a sample matrix, material is removed by small superjacent plasma which forms in the Ar carrier gas owing to high energy density in the focus of the laser beam. This process was termed plasma erosion by Abell (1991). In future investigations of bivalve shells, wavelength of 266 or $213 \mathrm{~nm}$ should be used, which are better suitable for the shell matrix to achieve crater diameter smaller than $20 \mu \mathrm{m}$. This was, however, not yet available in the laboratory when these analyses were performed.

All data are given as relative intensities, normalized to the Ca signal, or as weighted means $\left(m_{\mathrm{w}}\right)$ and weighted standard deviations $\left(s_{\mathrm{W}}\right)$ of relative intensities of the analyzed bivalves according to formula (1) (Barlow, 1989). Ca is homogenously distributed throughout the shell and therefore adequate as an internal standard. In doing so, effects of variations in sample surface texture, laser energy, and plasma energy could be excluded. The sensitivity of the detector system is different for each of the analyzed isotopes, and signals were corrected according to known intensities of isotopes of interest. Calculations were done for comparability of element ratios to literature data.

$m_{\mathrm{w}}=\frac{\sum\left(m_{\mathrm{i}} / s_{\mathrm{i}}{ }^{2}\right)}{\sum\left(1 / s_{\mathrm{i}}{ }^{2}\right)}, \quad s_{\mathrm{w}}=\sqrt{\frac{1}{\sum\left(1 / s_{\mathrm{i}}{ }^{2}\right)}}$

with $m_{\mathrm{W}}=$ weighted mean; $s_{\mathrm{W}}=$ weighted standard deviation; $m_{\mathrm{i}}=$ mean values of each umbo and year; $s_{\mathrm{i}}=$ standard deviation of each umbo and year.

\section{Results}

Fig. 2 presents the relative intensities of Fe as tracer for glacial sediment ablation and $\mathrm{Pb}$ as tracer for anthropogenic compounds versus years.

Both element signatures show a rapid decline within the first years of bivalve life (large diagrams), but in the time span from 1988 to 2003 no common trend was visible in either the iron or lead signatures in the four bivalve shells. In fact, no trend was visible for any of the measured elements (data not shown).

In a next step, weighted average values with weighted standard deviations of the four L. elliptica umbos were calculated for each element over bivalve lifetime (Eq. (1), Barlow, 1989). Graphs in Fig. 3 depict intensity means and standard deviations. All element signatures show a rapid decrease within the first 6-8 years of bivalve life. Yearly resolution was obtained until an age of 12. After this age mean values for groups of up to 4-year bands were calculated, due to the spot size of the laser crater. The same weighted value was assigned to each year in a group.

Table 2 gives the weighted means of relative intensities of trace elements in growth bands of four L. elliptica shells from 9-23 years of age in \% of the value in the first year segment.

Table 2

Weighted means of relative intensities of trace elements in growth bands of four Laternula elliptica shells from 9 to 23 years of age in $\%$ of the value in the first year segment, and element ratios calculated on the basis of the means of the relative element intensities in annual growth bands between 1990 and 2003

\begin{tabular}{lc}
\hline & $\%$ of first year \\
\hline $\mathrm{Al}$ & $9.4 \pm 0.6$ \\
$\mathrm{Mn}$ & $13.4 \pm 0.8$ \\
$\mathrm{Fe}$ & $5.9 \pm 0.3$ \\
$\mathrm{Cu}$ & $11.4 \pm 0.4$ \\
$\mathrm{~Pb}$ & $18.5 \pm 1.2$ \\
$\mathrm{U}$ & $6.9 \pm 0.5$
\end{tabular}

Ratio

\begin{tabular}{lr}
\hline $\mathrm{Fe} / \mathrm{Mn}$ & $26.8 \pm 9.4$ \\
$\mathrm{Fe} / \mathrm{Cu}$ & $3.8 \pm 1.7$ \\
$\mathrm{Al} / \mathrm{Mn}$ & $2.8 \pm 0.3$ \\
$\mathrm{Al} / \mathrm{Cu}$ & $0.4 \pm 0.1$ \\
\hline
\end{tabular}



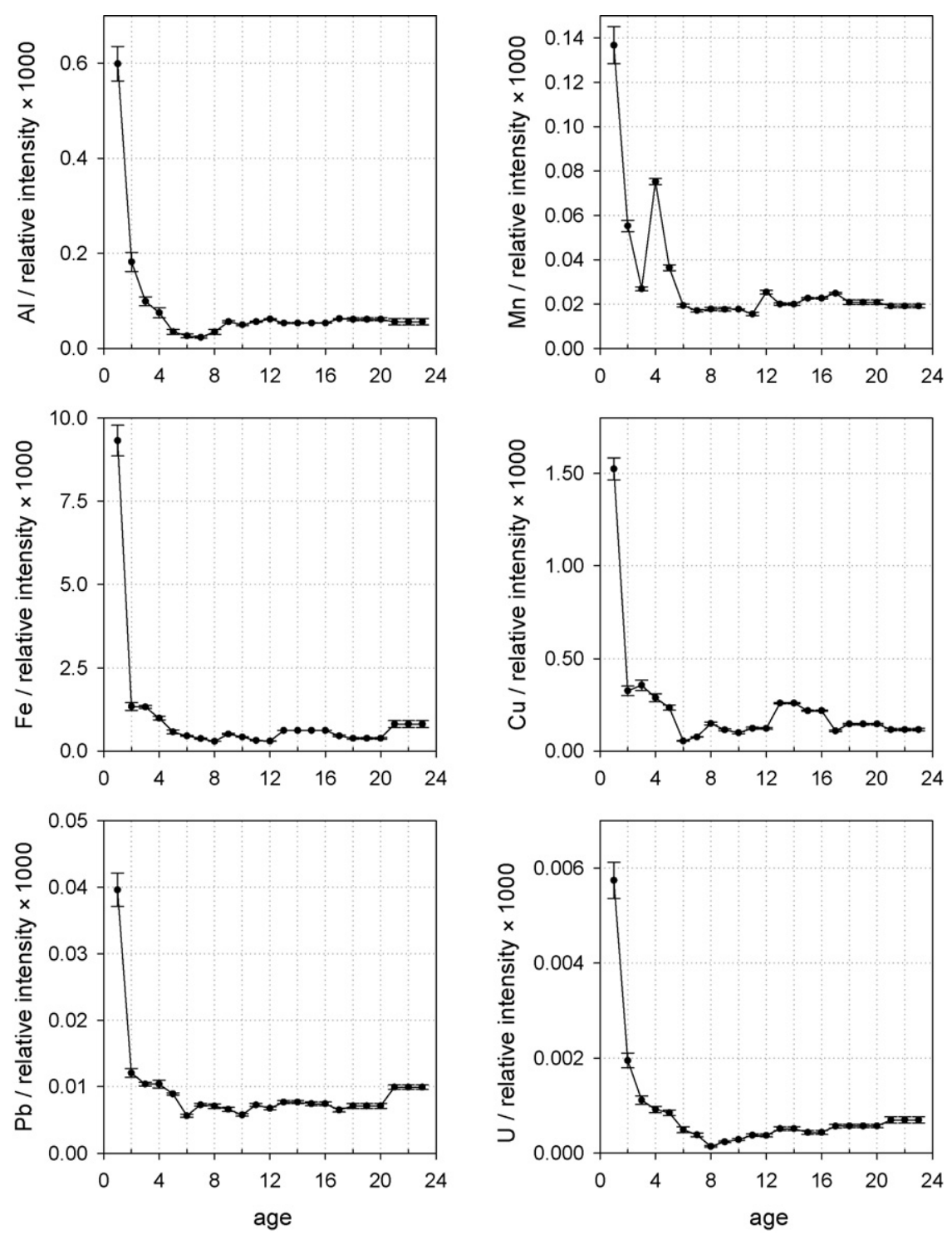

Fig. 3. Weighted means of $\mathrm{Al}, \mathrm{Mn}, \mathrm{Fe}, \mathrm{Cu}, \mathrm{Pb}$ and $\mathrm{U}$ normalized to Ca signal (relative intensities) $\pm \mathrm{S} . \mathrm{D}$. $(\times 1000)$ in annual growth bands of $L$. elliptica. Yearly resolution was obtained until an age of 12 . After this age mean values for groups of up to 4-year bands were calculated, due to the spot size of the laser crater. The same weighted value was assigned to each year in a group.

Relative accretion intensity of $\mathrm{Al}, \mathrm{Fe}$ and $\mathrm{U}$ decreased to $~ 7.5 \%$ compared to the first growth band. $\mathrm{Mn}$ and $\mathrm{Cu}$ decrease to $\sim 12.5 \%$, whereas $\mathrm{Pb}$ decreases to $18.5 \%$ of the concentration in the first growth band. Element ratios calculated on the basis of the means of the relative element intensities in annual growth bands between 1990 and 2003 were Fe/Mn: 26.8, Fe/Cu: 3.8, $\mathrm{Al} / \mathrm{Mn}: 2.8, \mathrm{Al} / \mathrm{Cu}: 0.4$. There is no correlation visible either between the relative intensities and growth process, or between the element ratios and growth process.

\section{Discussion}

\subsection{Can bivalve shells be used as environmental archives?}

The present study was designed to investigate, whether accelerated glacier melting observed over the past 10 years in Potter cove (see Abele et al., 2007; Schloss et al., 2007; Dierssen et al., 2002) might have caused an increase in Fe and of other elements, contained in ablated sediments and dust minerals, in the ultimate growth bands formed in bivalve umbos from the impacted region. Contrary to our hypothesis, element concentrations were highest in the early growth bands formed in the young bivalves and levelled off during the first 6-8 years of bivalve age. Following this initial life phase, the averaged element concentrations in the growth bands for 9 years and older animals remained constant, without signs of an increase in the most recent years.

Thus, neither did the intensified human activity at Jubany station within the last 15 years result in elevated $\mathrm{Pb}$ concentrations, nor could we find an increased iron signal from a potential increase of iron import from the ongoing glacial abrasion. Thus, glacial rock ablation may not have led to a measurable enrichment, because the iron from this natural source is always abundant in this coastal system and the animals may be capable 
of controlling the iron uptake. Still, we found iron to be 3-10fold higher concentrated in digestive gland of soft shell clams from the Potter Cove environment compared to soft shell clams (Mya arenaria) from the German Wadden Sea, where also the environmental concentrations are 10-fold lower (Estevez et al., 2002). Thus, the increase of iron from glacial ablation may be too marginal to be detected in bivalve shell archives against a huge environmental background at the present state. Richardson et al. (2001) compared trace element concentrations in growth bands of shells of the bivalve Modiolus modiolus from polluted and non-contaminated sites in the North Sea, using LA-ICP-MS. The sewage sludge contained elevated concentrations of $\mathrm{Cu}, \mathrm{Pb}$ and $\mathrm{Zn}$. Shells of bivalves from polluted sites turned out to be slightly higher loaded with metals than shells from non-polluted sites, except for events in 1972 and 1975, when $\mathrm{Zn}$ and $\mathrm{Pb}$ concentrations increased by a factor of 4-8 in the shells. In the study of Richardson and colleagues, only $\mathrm{Pb}$ showed decreasing concentrations in shell growth bands within the first 7 years of animal age. $\mathrm{Cu}$ and $\mathrm{Zn}$ accumulation remained constant during animal lifetime. Price and Pearce (1997) found concentration peaks of $\mathrm{Pb}, \mathrm{As}, \mathrm{Cu}, \mathrm{Zn}$ and $\mathrm{U}$ in shells of the cockle Cerastoderma edule (British Isles) collected at four sampling sites. All cockles are characterized by a sudden increase in metal content due to extreme anthropogenic pollution events, in particular $\mathrm{Zn}$ and $\mathrm{Cu}$. Only animals from one sampling location showed a synchronized pattern of increasing element concentrations immediately after the winter growth band.

\subsection{What is the reason for the decay of signal in the first years?}

The strong decay of element accretion in the first 8 years of bivalve age can be related to respiration mass $(R)$ data, obtained for the Jubany soft shell clam population by Philipp et al. (2005). The respiration mass index is defined as the product of whole animal respiration and body wet mass. The change of the index over animal lifetime is described by Eq. (2) (Von Bertalanffy, 1934). $R$ relates exponentially to body mass $(M)$, and the change in body mass over time (growth) depends exponentially on animal size $(S)$ at a given age.

$\log R=a \log M-b, \quad \log M=c \log S-d$,

$S_{t}=S_{\infty}\left(1-\mathrm{e}^{k\left(t+t_{0}\right)}\right)$

with $R=$ respiration mass in $\mathrm{J} \mathrm{d}^{-1} ; M=$ growth in body mass in $\mathrm{mm} \mathrm{mg}^{-1} ; S_{t}=$ growth in size in $\mathrm{mm} \mathrm{a}^{-1} ; t=$ time.

Parameter values for L. elliptica obtained from Philipp et al. (2005) are: $a=0.888, b=2.067, c=3.074, d=2.531$; $S_{\infty}=$ asymptotic maximum size $(=91.55 \mathrm{~mm}) ; k=$ growth constant $(=0.108) ; t_{0}=$ age at which lengths would be zero $(=-1.598)$

Plotting the curve for respiration mass (dashed line) and its first (dotted line) and second (solid line) derivative over animal life time (Fig. 4) results in an inflection point at an age of 7.9 years in the 2 nd derivate. This point marks a change in the increase of $R$ (1st derivate), which means a progressive slowing of the increase in age-dependent whole animal metabolic rate.

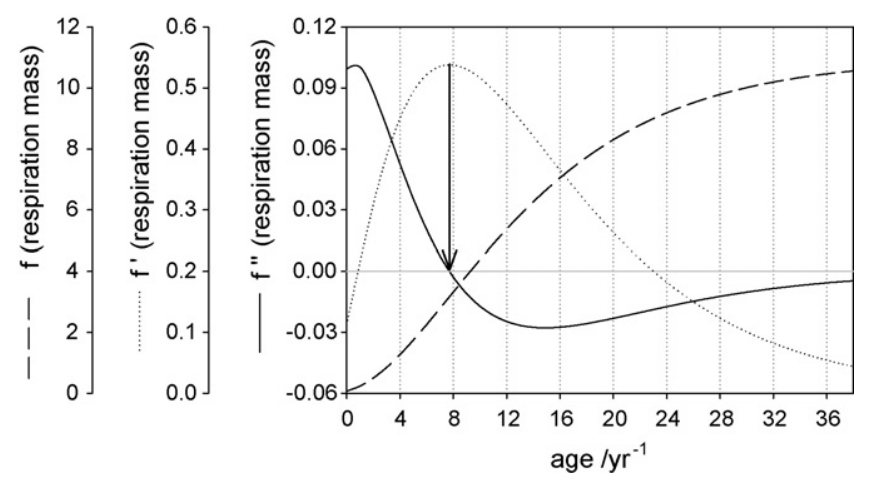

Fig. 4. Respiration mass (-) and its 1 st ( ..) and 2nd (- derivative of $L$. elliptica $\left(\log R=a \times \log M-b\right.$, Philipp et al., 2005) vs. age year ${ }^{-1}$. Inflection point (arrow) at an age of 7.9, indicating progressive slow down in the increase in age-dependent metabolic rate.

Moreover, it coincides with the end of the decrease in element accretion in the umbo between 6 and 8 years of bivalve age. Obviously, young, fast growing and intensely respiring bivalves accumulate heavy metals at higher rates into the shell matrix than older animals. Importantly, the higher accumulation does not reflect a denser packing of the umbo matrix in young animals, because the calculated intensities were Ca-normalized. This speaks for high uptake of heavy metals and less discrimination between wanted and unwanted material in younger than older specimens.

The importance of the analyzed elements for bivalve physiology is variable and complex, but it seems unlikely that any of these elements could be physiologically limiting under Antarctic coastal conditions. Iron and copper are both essential micronutrients as well as active Fenton chemicals, which must be bound to storage and transport proteins in invertebrate tissues, to prevent oxygen radical formation (Abele and Puntarulo, 2004). To see, whether the animals discriminate between different elements, ratios in shell material of $L$. elliptica were compared to the ratios in seawater, sedimenting particles (Abele et al., 2007) and basal ratios from the Earth's crust (Wedepohl, 1995) (Table 3). Water samples and sedimenting particles in Potter Cove were taken in December 2002 and are representative of the two possible uptake mechanisms of heavy metals into the bivalve tissue from the dissolved metal pool or through particle ingestion. Lower ratios ( $\mathrm{Fe} / \mathrm{Mn}$ and $\mathrm{Fe} / \mathrm{Cu}$ ) in L. elliptica shell material indicate preferential incorporation of $\mathrm{Cu}$ and $\mathrm{Mn}$ over $\mathrm{Fe}$ into the umbo matrix. Indeed, both metals can substitute $\mathrm{Ca}^{2+}$ ions in the calcium carbonate crystals (Tynan et al., 2005). Recent investigations of L. elliptica tissue concentrations show that $\mathrm{Cu}$ appears to be concentrated in digestive gland $(\mathrm{Fe} / \mathrm{Cu}=13-21)$ and gill tissues $(\mathrm{Fe} / \mathrm{Cu}=15)$ (Ahn et al., 2001), indicating increased demand for $\mathrm{Cu}$ in the Antarctic soft shell clam. For that matter, $\mathrm{Cu}$ containing hemocyanin is the most common oxygen-binding pigment in non-hemoglobin-containing molluscs (Winzerling and Law, 1997) and, although not reported heretofore, it seems possible that copper containing respiratory proteins could exist in L. elliptica. Moreover, $\mathrm{Cu}$ is the catalytic ion in Fe-oxidases that oxidise ferrous $\mathrm{Fe}$ (II) to ferric $\mathrm{Fe}$ (III) for the binding to Fe transport and storage proteins (Winzerling and Law, 1997 
Table 3

Element ratios in water samples (30 m depth, January 2004) and sediment trap material in Potter Cove (22 December 2002), the Earth's crust and in the umbo matrix of four L. elliptica (average \pm S.D.) calculated on the basis of the means of the relative element intensities in annual growth bands between 1990 and 2003

\begin{tabular}{llrrr}
\hline & $\mathrm{Fe} / \mathrm{Mn}$ & $\mathrm{Fe} / \mathrm{Cu}$ & $\mathrm{Al} / \mathrm{Mn}$ \\
\hline Water sample (30 m depth) (Abele et al., 2007) & $50.5 \pm 3.0$ & $133 \pm 52.3$ & \\
Sediment trap sample (Abele et al., 2007) & $55.8 \pm 4.7$ & $323 \pm 172$ & \\
Earth's crust (Wedepohl, 1995) & 58.6 & 2160 & $3.8 \pm 1.7$ & \\
L. elliptica (umbo) & $26.8 \pm 9.4$ & 5415 & $0.4 \pm 0.1$ \\
\hline
\end{tabular}

for review). It looks like the animals are able to discriminate against the uptake of the relatively toxic element Fe, which is a more efficient Fenton catalyst than $\mathrm{Cu}$ and induces formation of reactive oxygen species (ROS) in animal tissues, including very aggressive hydroxyl radicals $\left(\mathrm{OH}^{\bullet}\right)$ (Estevez et al., 2002). Comparing $\mathrm{Fe} / \mathrm{Mn}$ and $\mathrm{Fe} / \mathrm{Cu}$ to $\mathrm{Al} / \mathrm{Mn}$ and $\mathrm{Al} / \mathrm{Cu}$ (Table 3), $\mathrm{Al}$ is even more discriminated than iron. The Fe/Mn ratio in L. elliptica is 2.2 times lower than the ratio in the Earth's crust, where $\mathrm{Al}$ is the most highly concentrated metal. $\mathrm{Al} / \mathrm{Mn}$ amounts to 2.8 in the shells, 53 times lower than in the Earth crust. Pathophysiology of $\mathrm{Al}$ in humans involves oxidative stress in the brain and, moreover, bone diseases, because $\mathrm{Al}$ competes with elements like $\mathrm{Mg}$ and $\mathrm{Ca}$ of similar atomic size and electric charge (http://www.emedicine.com/med/topic113.htm). It is presently unknown what effects $\mathrm{Al}$ can have in bivalve physiology, however, possibly, this element can be highly toxic if not excluded by the animals. Interestingly, aluminium is not measured or referred to in any of the available surveys of metal accumulation in bivalve shells or soft tissues that we are aware of.

\subsection{Conclusions and outlook}

We could clearly show that the incorporation of elements into the umbo matrix of L. elliptica is primarily coupled to respiration mass. No change due to global warming or anthropogenic activity could so far be discerned. However, it may well be possible that with increased accuracy and technical refinement, which improve spatial resolution, further analyses of bivalve shell material may enable to obtain higher time resolute information. The use of a laser ablation (LA) system with a wavelength of $266 \mathrm{~nm}$ should be more applicable to achieve higher sensitivity and smaller crater diameter. More information on other elements in bivalve umbo matrices will be gained, by coupling an inductively coupled plasma time of flight mass spectrometer (ICP-TOF-MS) to the LA-System. Also, higher numbers of animals have to be analyzed for final conclusions.

\section{Acknowledgements}

We thank Lic Adrian Atencio, Instituto Antarctico, Buenos Aires, for collaboration on the environmental iron concentrations in Jubany and Ilse Stölting for invaluable technical support. Thanks to Tom Brey for lively and competent discussions of the shell archive topic. Moreover, we received all necessary support on Jubany Base and especially from the 2003 Argentinean diving team, who collected L. elliptica in Potter Cove. We would also like to thank two anonymous referees for constructive comments.

\section{References}

Abele, D., Puntarulo, S., 2004. Formation of reactive species and induction of antioxidant defence systems in polar and temperate marine invertebrates and fish. Comp. Biochem. Physiol. Part A 138, 405-415.

Abele, D., Atencio, A., Dick, D., Gonzales, O., Kriews, M., Meyer, S., Philipp, E., Stölting, I., 2007. Iron, copper and manganese discharge from glacial melting into Potter Cove and metal concentrations in Laternula elliptica shells. In: Wiencke, C., Ferreyra, G., Abele, D., Marenssi, S. (eds.), The Potter Cove coastal ecosystem, Antarctica. Synopsis of research performed 1999-2006 at the Dallmann Laboratory and Jubany Station, King George Island (Isla 25 de Mayo). Rep. Polar Mar. Res., in press.

Abell, I.D., 1991. Performance benefits of optimisation of laser ablation sampling for ICP-MS. In: Holland, J.G., Eaton, A.N. (Eds.), Application of Plasma Source Mass Spectrometry. Royal Society of Chemistry, pp. 209-271.

Ahn, I.-Y., Kang, J., Kim, K.-W., 2001. The effect of body size on metal accumulations in the bivalve Laternula elliptica. Ant. Sci. 13 (4), 355-362.

Bagnyukova, T.V., Chahrak, O.I., Lushchak, V.I., 2006. Coordinated response of goldfish antioxidant defenses to environmental stress. Aquat. Toxicol. 78, 325-331.

Barlow, R., 1989. Statistics: A Guide to the Use of Statistical Methods in the Physical Science. The Manchester Physics Series. Wiley, New York, p. 54.

Brey, T., Mackensen, A., 1997. Stable isotopes prove shell growth bands in the Antarctic bivalve Laternula elliptica to be formed annually. Polar Biol. 17, 465-468.

Carriker, M.R., Swann, C.P., Ewart, J.W., 1982. An exploratory study with the proton microprobe of the ontogenetic distribution of 16 elements in the shell of living oyster. Mar. Biol. 69, 234-246.

Dierssen, H.M., Smith, R.C., Vernet, M., 2002. Glacial meltwater dynamics in coastal waters west of Antarctic Peninsula. Proc. Natl. Acad. Sci. 99, 1790-1795.

Estevez, M.S., Abele, D., Puntarulo, S., 2002. Lipid radical generation in polar (Laternula elliptica) and temperate (Mya arenaria) bivalves. Comp. Biochem. Physiol., Part B 132, 729-737.

Huanxin, W., Lejun, Z., Presley, B.J., 2000. Bioaccumulation of heavy metals in oyster (Crassostrea virginica) tissue and shell. Environ. Geol. 38, 1216-1226.

Jing, G., Li, Y., Xie, L., Zhang, R., 2006. Metal accumulation and enzyme activities in gills and digestive gland of pearl oyster (Pinctada fucata) exposed to copper. Comp. Biochem. Physiol., Part C 144, 184-190.

Kriews, M., Reinhard, H., Dunker, E., Beninga, I., Ruhe, W., 2004a. An analytical system for the detection of spatial patterns of trace element distribution in frozen samples. Utility Patent, DE 202004005 991.6.

Kriews, M., Reinhardt, H., Dunker, E., Hoffmann, E., Lüdtke, C., Beninga, I., 2004b. Analytical procedure for the detection of trace element distribution patterns in solid samples. Patent, EP-DE 50105 651.3-08.

Momo, F., Kowalke, J., Schloss, I., Mercuri, G., Ferreyra, G.A., 2002. The role of (Laternula elliptica) in the energy budget of Potter Cove (King George Island, Antarctica). Ecol. Model. 155, 43-51. 
Mubiana, V.K., Blust, R., 2007. Effects of temperature on scope for growth and accumulation of $\mathrm{Cd}, \mathrm{Co}, \mathrm{Cu}$ and $\mathrm{Pb}$ of the marine bivalve Mytilus edulis. Mar. Environ. Res. 63, 219-235.

Philipp, E., Brey, T., Pörtner, H.O., Abele, D., 2005. Chronological and physiological ageing in a polar and a temperate mud clam. Mech. Ageing Dev. 126, 598-609.

Pearce, N.J.G., Westgate, J.A., Perkins, W.T., Preece, S.J., 2004. The application of ICP-MS methods to tephrochronological problems. Appl. Geochem. 19, 289-322.

Price, G.D., Pearce, N.J.G., 1997. Biomonitoring of pollution by Cerastoderma edule from the British Isles: a laser ablation ICP-MS study. Mar. Pollut. Bull. 34 (12), 1025-1031.

Raith, A., Perkins, W.T., Pearce, N.J.G., Jeffries, T.E., 1996. Environmental monitoring on shellfish using UV laser ablation ICP-MS. Fresenius J. Anal Chem. 355, 789-792.

Reinhardt, H., Kriews, M., Miller, H., Schrems, O., Lüdke, C., Hoffmann, E., Skole, J., 2001. Laser ablation inductively coupled plasma mass spectrometry: a new tool for trace element analysis in ice cores. Fresenius J. Anal. Chem. 370, 629-636.

Richardson, C.A., Chenery, S.R.N., Cook, J.M., 2001. Assessing the history of trace metal $(\mathrm{Cu}, \mathrm{Zn}$ and $\mathrm{Pb})$ contamination in the North Sea through laser ablation ICP-MS of horse mussel, Modiolus modiolus shells. Mar. Ecol. Prog. Ser. 121, 157-167.
Richardson, C.A., 2001. Molluscs as archive of environmental change. Oceanogr. Mar. Biol. 39, 103-164.

Schloss, I.R., Ferreyra, G. A., González, O., Atencio, A., Fuentes, V., Tosonotto, G., Mercuri, G., Sahade, R., Tatián, M., Abele, D., 2007. Long term hydrographic conditions and climate trends in Potter Cove. In: Wiencke, C., Ferreyra, G., Abele, D., Marenssi, S. (eds.), The Potter Cove Coastal Ecosystem, Antarctica. Synopsis of research performed 1999-2006 at the Dallmann Laboratory and Jubany Station, King George Island (Isla 25 de Mayo). Rep. Polar Mar. Res., in press.

Tynan, S., Eggins, S., Kinsley, L., Welch, S.A., Kirste, D., 2005. Mussel shells as environmental tracers: an example from the Loveday Basin. In: Roach, I.C. (Ed.), Regolith 2005-Ten Years of CRC LEME. CRC LEME, pp. 314 317.

Von Bertalanffy, L., 1934. Untersuchungen über die Gesetzlichkeit des Wachstums. Arch. F. Entwicklungsmechanik d. Organismen 131, 613652.

Wedepohl, K.H., 1995. The composition of the continental crust. Geochim. Cosmochim. Acta 59 (7), 1217-1232.

Winzerling, J.J., Law, J.H., 1997. Comparative nutrition of iron and copper. Annu. Rev. Nutr. 17, 501-526.

Yap, C.K., Ismail, A., Tan, S.G., 2003. Background concentrations of Cd,Cu, $\mathrm{Pb}$ and $\mathrm{Zn}$ in the green-lipped mussel Perna viridis (Linnaeus) from Peninsular Malaysia. Mar. Poll. Bull. 46, 1035-1048. 